\title{
Analysis of study results of development of foreign language communicative comptence of lecturers of higher military educational institutions
}

\author{
M. Aristarkhova \\ National Defense University of Ukraine named after Ivan Cherniakhovskyi \\ Corresponding author. E-mail: aristarkhovamargarita@gmail.com
}

Paper received 06.08.20; Accepted for publication 24.08.20.

\begin{abstract}
https://doi.org/10.31174/SEND-PP2020-236VIII94-02
\end{abstract}
\begin{abstract}
The article deals with the essence of theoretic and experimental check of author's andragogical model of development of foreign language communicative competence of lecturers of higher military educational institutions into educational process. The definition of "foreign language communicative competence" and its structure is proposed by author. The article reveals the main stages of experiment of foreign language communicative competence development. The results of pedagogical experiment on development foreign language communicative competence were presented and substantiated with help of Fisher F-test. The efficiency of the andragogical model was statistically proved.
\end{abstract}

Keywords: military education, lecturers of HMEI, foreign language communicative competence, pedagogical experiment, outcomes.

Introduction. Implementation of NATO educational standards in the system of lifelong learning depends on development of foreign language communicative competence of lecturers of Higher Military Educational Institutions (HMEI) as leaders of reforming, who are responsible for introduction of new educational content in the military and pedagogical process. Foreign language training of lecturers of HMEI provides adoption, implementation and enrichment of best practices in the modern educational practice.

The review of publications on the topic of the article. In studies on issue of communicative competence development the scientists achieved the following conclusions:

foreign language communicative competence refers to learner's to use communicative strategies and mechanisms, which are necessary in order to provide efficient interaction [Nikolaeva, 2011];

the content of foreign language communicative competence includes the knowledge about communication under different circumstances with different communicants, and also verbal and nonverbal basics of interaction, ability of its efficient usage in the specific communication as a addressant and as a addressee.[Batsevych, 2009].

The communicative competence of a lecturer is a dynamic combination knowledge, main techniques and means of interpersonal communication, styles of speech, practical experience of communication in different languages; abilities constantly to enrich own speech, to establish professional and pedagogical communication, to achieve his/her objectives; ability to produce own pedagogical style of communication on dialogical basis taking into account norms of the modern literary language, rules of pedagogical ethics, aesthetics of verbal and nonverbal activity, demonstrate culture of professional and pedagogical communication, ability to use interactive communicative technologies. [Vitchenko, 2017].

The given example brightly shows the lack of understanding of foreign language communicative competence of a lecturer, and as a result differences in approaches to its development.

The Purpose of the Article. The aim of the article is to define the context of foreign language competence of lecturers and to check statistical significance of the andragogical model providing its development.
Research Methods. The following empirical methods of research were used: observation, questionnaire, tests ("Communicative and Organizational Skills Diagnostics", Rokeach Methodology of Personality Orientation, Methodology of Diagnostics of Evaluation of Self-Monitoring in Communication by M. Snyder, Methodology of Diagnostics of Communicative Attitude by V. Boyko, MaddusSherer Self-Efficiency Test, situational test based on methodology "Business Situations" by N. Khytrova, standardization language test in accordance with STANAG 6001). The Fisher F-test was used to prove statistical importance of results between percentage of two samples (EG and CG).

The results and discussion. Foreign language communicative competence of Lecturers of HMEI is an instrument, which provides development of professional competence, readiness of military lecturers to solve educational and pedagogic tasks on the basis of gained knowledges, skills, acquirements, formed culture of pedagogical communication, ethics, aesthetics of pedagogical activity acquired during foreign language training. [Vitchenko, 2017]. It provides readiness of lecturers constantly to enhance knowledge of foreign language, improve his/her own professional competence, adopt best practices of military professionals in accordance with NATO standards and implement all the abovementioned in the educational and professional training of military students.

Foreign language communicative competence of lecturers of higher military educational institutions is to our mind an integral indicator of lecturer's readiness for foreign language efficient communication, subject-subject interaction with communicants on the basis of dynamic combination of lexical, phonetical, grammatical, stylistic cross cultural, verbal and nonverbal means of language knowledge, strategies and tactics of communication, experience of foreign language communication, "adjusting to" actual social and professional roles, ability to navigate in different situations of foreign language communicative situations, use vocabulary to solve professional problems; ability to make personal foreign language communicative style in accordance with norms of modern language, ethical rules of intercultural communication. We may see from the essence of this definition, that foreign language communicative competence is a integral formation, which is comprised of personal qualities, abilities, skills of a lecturer, that enable 
him/her to enhance military educational process according to the requirements of contemporaneity.

The essential characteristics of foreign language communicative competence of lecturers of HMEI give an opportunity to outline the following structural components:

Inter-personal skills - an ability of a lecturer HMEI in any situation to get on well with people during educational foreign language communication, use different styles of communication and ways of communicative behavior, copious vocabulary, increase constantly vocabulary through new lexis;

Flexibility - an ability to respond quickly and properly to foreign language communicative behavior of interlocutor, attain a common understanding and cooperation with help of foreign language;

Creativity - an ability to generate no standard solutions, use strategies and tactics of foreign language communication creatively;

Interactivity - an ability to mend interpersonal communication, solve difficult pedagogical situations and problems with usage of foreign language communicative methods.

Reflexivity - an ability to comprehend critically pedagogical communication.

Foreign language knowledge and skills - lexical, phonetical, grammatical, stylistic cross cultural, verbal and nonverbal means of language knowledge.

The research was held in two stages: summative and formative assessment.

Summative assessment was held during 2017-2018 and was aimed at definition of importance of foreign language communicative competence of HMEI lecturers in the lifelong learning system. The questionnaire of military lecturers was held in: National Defence University of Ukraine named after Ivan Cherniakhovskyi (Kyiv), Hetman Petro Sahaidachnyi National Army Academy (Lviv), Zhytomyr Military Institute named after Serhyi Korol'ov (Zhytomyr), Ivan Kozhedub National Air Force University (Kharkiv). The majority of examined lecturers stated, that this problem requires a special attitude due to expansion of military and educational cooperation, increasing professional competence of lecturers [Aristarkhova, 2019].

Formative assessment was held during 2017-2020 and was aimed at approbation of the model of foreign language communicative competence development of HMEI lecturers in the system of post-graduate education, its diagnostics through defined components, educational and methodological support. The research was held under real conditions of educational process in the National Defence University of Ukraine named after Ivan Cherniakhovskyi. Sample of the research consisted of 74 lecturers. There was one control group (CG) and one experimental group (EG).

Definition of integral level of foreign language communicative competence development of HMEI lecturers was done in accordance with the following formula:

$$
K_{\Sigma}=K_{f l}+K_{c}+K_{i}+K_{f}+K_{r}+K_{c r}
$$

where $K_{f l}$ - results of foreign language knowledge and skills evaluation;

$K_{c}-$ results of inter-personal skills evaluation;

$K_{i}$ - results of interactivity evaluation;

$K_{f}-$ results of flexibility evaluation;
$K_{r}-$ results of reflexivity evaluation;

$K_{c}-$ results of creativity evaluation.

The importance of which coefficient was defined by expert evaluation method.

The integral level of foreign language communicative competence development of HMEI lecturers at the stage of formative assessment were $\mathrm{CG}=63,73, \mathrm{EG}=63,62$.

The data shows, that the difference between amount of respondents with high, sufficient, average and low level in $\mathrm{CG}$ and EG is insignificant at this stage of research.

According to the results of diagnosing its was defined that the differences between CG and EG at the beginning of the formation experiment were not statistically significant.

Formative assessment was aimed at checking of developed model of foreign language communicative competence development of HMEI lecturers in the post-graduate system. The same methodologies for evaluation of each component were used at the beginning and in the end of study. The training in the EG was held in accordance with the developed andragogical model based on usage of interactive technologies, while traditional methodologies were used for training in the CG. The efficiency of the andragogical model realization also lies in the combination of all organizational forms of learning (formal, non-formal, selfimprovement, self-development and foreign language communicative experience). The leading characteristics for development of foreign language communicative competence are interactive cooperation, creation of active foreign language environment, self-improvement of foreign language communicative competence by means of distance learning courses. [Aristarkhova, 2020].

According to the results of final diagnosing there were defined the essential changes of values of an integral index of foreign language communicative competence development in the EG, while there were no such changes in the CG. The most essential positive changes were achieved in the EG in development of inter personal skills (EG for 1,23; while CG for 0,354), interactivity (EG for 1,67; while CG for 0,42), creativity (EG for2,008; while CG for 0,838), foreign language knowledge and skills (EG for 2,99; while $\mathrm{CG}$ for 0,8). Received data shows the significant communicative potential of HMEI lecturers in their foreign language communicative potential. The dynamics of integral index change is shown in the table 1 .

Table 1. Levels of Foreign Language Communicative Competence Development

\begin{tabular}{|c|l|c|c|c|c|}
\hline \multirow{2}{*}{ № 3/II } & \multirow{2}{*}{$\begin{array}{l}\text { Results of } \\
\text { Evaluation }\end{array}$} & \multicolumn{2}{|c|}{ EG } & \multicolumn{2}{|c|}{ Experiment Results } \\
\cline { 3 - 6 } & & $\begin{array}{c}\text { at the } \\
\text { beginning }\end{array}$ & in the end & $\begin{array}{c}\text { at the be- } \\
\text { ginning }\end{array}$ & $\begin{array}{c}\text { in the } \\
\text { end }\end{array}$ \\
\hline 1 & $K_{c}(\%)$ & 14,78 & 15,134 & 14,97 & 16,2 \\
\hline 2 & $K_{i}(\%)$ & 13,81 & 14,23 & 13,6 & 15,27 \\
\hline 3 & $K_{f}(\%)$ & 6,33 & 6,71 & 6,36 & 7,12 \\
\hline 4 & $K_{r}(\%)$ & 6,403 & 6,501 & 6,47 & 6,69 \\
\hline 5 & $K_{c}(\%)$ & 6,412 & 7,250 & 6,423 & 8,431 \\
\hline 6 & $K_{f l}(\%)$ & 16,00 & 16,8 & 15,81 & 18,8 \\
\hline 7 & $K_{\Sigma}$ & $\mathbf{6 3 , 7 3}$ & $\mathbf{6 6 , 6 5}$ & $\mathbf{6 3 , 6 2}$ & $\mathbf{7 2 , 5 1 1}$ \\
\hline
\end{tabular}

Results of our own research

Verification of statistical significance of the received results with the help of Fisher F-test $(2,44)$ and allowed us to define statistically significant changes in EG and absence 
of such changes in $\mathrm{CG}$, that reflects the influence made on lecturers by the proposed andragogical model. So, the received results of research on effectiveness of implementation of substantiated adragogical model into educational process has been proven.

Conclusions. The conducted research of foreign language communicative competence of lecturers of higher military educational institutions allowed to implement author's andragogical model in the educational process. According to the defined problematic issues. Conducted statis- tical analysis of the results of experimental and control groups defined statistical significance of received results and allows us to affirm the effectiveness of the implemented model according to all components of foreign language communicative competence. The results of pedagogical experiment confirmed that the improvement, selfdevelopment process formed individual requirements for professional growth, to improve his/her own professional competence, adopt best pedagogical practices as well as military ones and its introduction into educational process.

\section{REFERENCES}

1. Aristarkhova M.S.(2019) Modern Approaches to Development of Foreign Language Communicative Competence of Military Lecturers. Science and Education a New Dimension: Pedagogy and Psychology: VII(82), 7-11.

2. Aristarkhova M.S. (2020) The Model of Foreign Language Communicative Competence Development of HMEI Lecturers in the Postgraduate System of Education. Actual Issues of Humanitarian Sciences. 30, 57-63
3. Batsevych F. S. (2009) Basics of Communicative Linguistics. Kyiv: Akademia.

4. Vitchenko A. O., Osodlo V. I. (2017) Pedagogy of Higher Military School. Kyiv: NDU of Ukraine named after Ivan Cherniakhovskyi.

5. Nikolaieva S. Yu. (2011) Methodology of Formation of Intercultural Foreign Language Communicative Competence. Kyiv: Lenvit. 